\title{
PENGARUH FISIKA, KIMIA DAN MIKROBIOLOGI TERHADAP KERUSAKAN PLASTIK
}

\author{
Oleh : Ir. Siti Rochani
}

\section{Pendahuluan}

Plastik dapat mengalami kerusakan sebagaimana logam atau kayu, oleh pengaruh fisika. kimia maupun mikrobia. Penggunaan plastik ditentukan oleh sifatsifat yang dipunyai misalnya : tegangan putus. perpanjangan putus, gaya pegas (resiliency). sifat isolasi listrik, sifat tembus pandang. ketahanan terhadap beberapa sifat yaitu panas, cahaya. uap air. serangga, oksigen. ozon dan lain-lain.

Tidak semua plastik mempunvai sifat-sifat tersebut diatas. hal ini disebabkan karena adanya beberapa penambahan ingredien seperti bahan pelunak. bahan penstabil, bahan pengisi. pewarna maupun bahan tambahan/aditif yang lain yang masing-masing bahan tersebut mempunyai pengaruh terhadap hasil akhir produk. Untuk memperkirakan ketahanan plastik terhadap kerusakan diperlukan pengetahuan tentang karakteristik bahan-bahan/ingredien tersebut, komposisi bahan serta kondisi proses.

Pada pembuatan barang plastik macam dan jumlah aditif yang ditambahkan sangat bervariasi. Aditif yang paling banyak ditambahkan adalah plasticizer dan filler, sehingga kedua bahan tersebut yang paling besar pengaruhnya terhadap kerusakan produk plastik. Perbaikan salah satu akan menurunkan sifat yang lain. Seperti misalnya penambahan filler serbuk gergaji bisa memperbaiki sifat ketahanan pukul, tetapi menurunkan ketahanan terhadap uap air dan ketahanan terhadap hewanhewan kecil.

Pengaruh bahan pelunak (plasticizer) terhadap pertumbuhan jamur

Plasticizer merupakan bahan yang bisa mengurangi kerapuhan plastik dengan cara melumasi antar individu rantai molekul. Bahan ini umumnya mempunyai titik didih tinggi dan volatilitasnya rendah. Pencampuran plasticizer kedalam kompon plastik biasanya berkisar $20-50 \%$. Penggunaan plasticizer perlu diperhitungkan untuk menghindari kerusakan pada produk akhir.

Ditinjau dari ketahanan terhadap mikrobiologi, jenis plasticizer yang ditambahkan pada plastik perlu lebih diperhatikan dibanding dengan aditif yang lain karena beberapa jenis plasticizer tidak tahan jamur.

Kompon yang mengandung plasticizer berupa residu asam lemak peka terhadap serangan jamur. Yang termasuk golongan ini adalah acetat, propionat, butyrate, caprylate, laurat, myristat, oleat dan ricinolat.

Golongan minyak yang tidak tahan terhadap serangan jamur adalah minyak 
castor, minyak tung, linseed, cotton seed, dehidrated castor oil dan triacetin. Tung il sedikit lebih tahan dari pada natural oil yang lain, sedangkan cyclohexyl lactate (hydroksi propionic acid ester) tahan terhadap serangan jamur.

Golongan ester dari dicarboxilic acid (rantai lurus), sebagian besar peka erhadap jamur, tetapi sedikit lebih tahan dari pada yang monocarboxylic acid Succinat, adipat, azelat dan sebacat semuanya diserang jamur sedangkan diethyl hexyl azelat, diethyl succinat dan methyl cyclohexyl oxalat mempunyai ketahanan vang baik terhadap jamur. Di-n-butyl tartrat, derivat hydroxylated dicarboxylic acid kebal terhadap jamur. Derivatif dari aliphatic tricarboxylic acid-aconitic, citric dan tricarballylic mempunyai ketahanan yang bagus.

Pada derivative monocarboxylic aromatic acid, benzoyl benzoat diserang jumur sedangkan ethyl o benzoyl benzoat tidak diserang jamur. Terpenes abietic cid dan hydrogenated methyl abictate menunjukkan tahan serangan. Beberapa macam phtalat sebagian besar kebal serangan. kecuali ada beberapa yang sedikit erserang jamur misalnya pada diamyl phtalat. diphenyl phtalat. ethyl 2 methyl 2 nitropropyl phtalat. dibenzyl phtalat, buthyl phtalat, dimethyl cyclohexyl phtalat. nethyl phtalat. dicapryl phtalat, tetapi secara umum phtalat tahan serangan jamur. Dari jenis organik phosphat sebagian besar menunjukkan tahan serangan amur. kecuali tryphenyl phosphat dan tertier phosphat dari 2 nitro 2 methyl propanol. Phosphat juga digolongkan tahan serangan jamur.

Derivative glicerol, pentaeritritol dan sorbitol menunjukkan sedikit ada pertumban jamur kecuali dipentaerytritol hexacetat dan hexabutirat menunjukkan pertumbuhan jamur yang banyak.

Derivat glicol mempunyai ketahanan yang bervariasi. Jenis-jenis yang tidak tahan pertumbuhan jamur sedang sampai berat adalah : diethylen glycol ethyl ether acetat, butyl ether acetat, ethylen glycol laurat, ethylen glycol ethyl ether laurat, diethylen glycol monolaurat, diethylen glycol ethyl ether laurat, ethylen glycol methyl ether oleat, ethylen glycol methyl ether acetyl ricinoleat, diethylen glycol ethyl ether stearat, tetraethylene glycol monostearat dan distearat. Sedangkan jenis yang tahan serangan jamur adalah : diethylen glycol, dimethyl glycol phtalat, diethylen glycol dipropionat, triethylen glycol di (2-ethylhexoat), diethylen glycol di ( 2 ethyl butyrat) diacetat dan dipropionat dari 2 nitro 2 methyl-1,3-propanediol.

Derivat glicolic acid menunjukkan tidak tahan diserang jamur. Derivat glycol dan glycolic acid yang terdiri dari rantai alifatis yang tidak lebih dari 10 atom carbon tahan serangan jamur.

Bahan-bahan yang lain seperti chlorinated hydrocarbon, silicon oil, 2 toluensulfonat, ortho dan para toluen ethyl sulfonamide, sulfonated oil, coal tar oil, petroleum oil, diphenyl, diamyl naphtalen, diamylphenoxyethanol, benzophenon, methylamyl dihexyl cyclohexanon, diphenyl sulfone, triphenyl guanidin, butyraldehyde, chlorowax, decalin (hydrogenated naphtalen), ethyl acetanilide dan butadien acrylonitril, semuanya tidak menyebabkan tumbuhnya jamur. Sedangkan bahan-bahan yang menyebabkan pertumbuhan jamur adalah : refined tall oil, nitril dari asam oleat dan linoleat, resin glycol sebacat, asam lemak dimethylamide.

\section{Ketahanan plastik terhadap serangan mikroorganisme}

Faktor ketahanan terhadap mikroorganisme dari masing-masing jenis plastik dapat dilihat pada tabel dibawah ini.

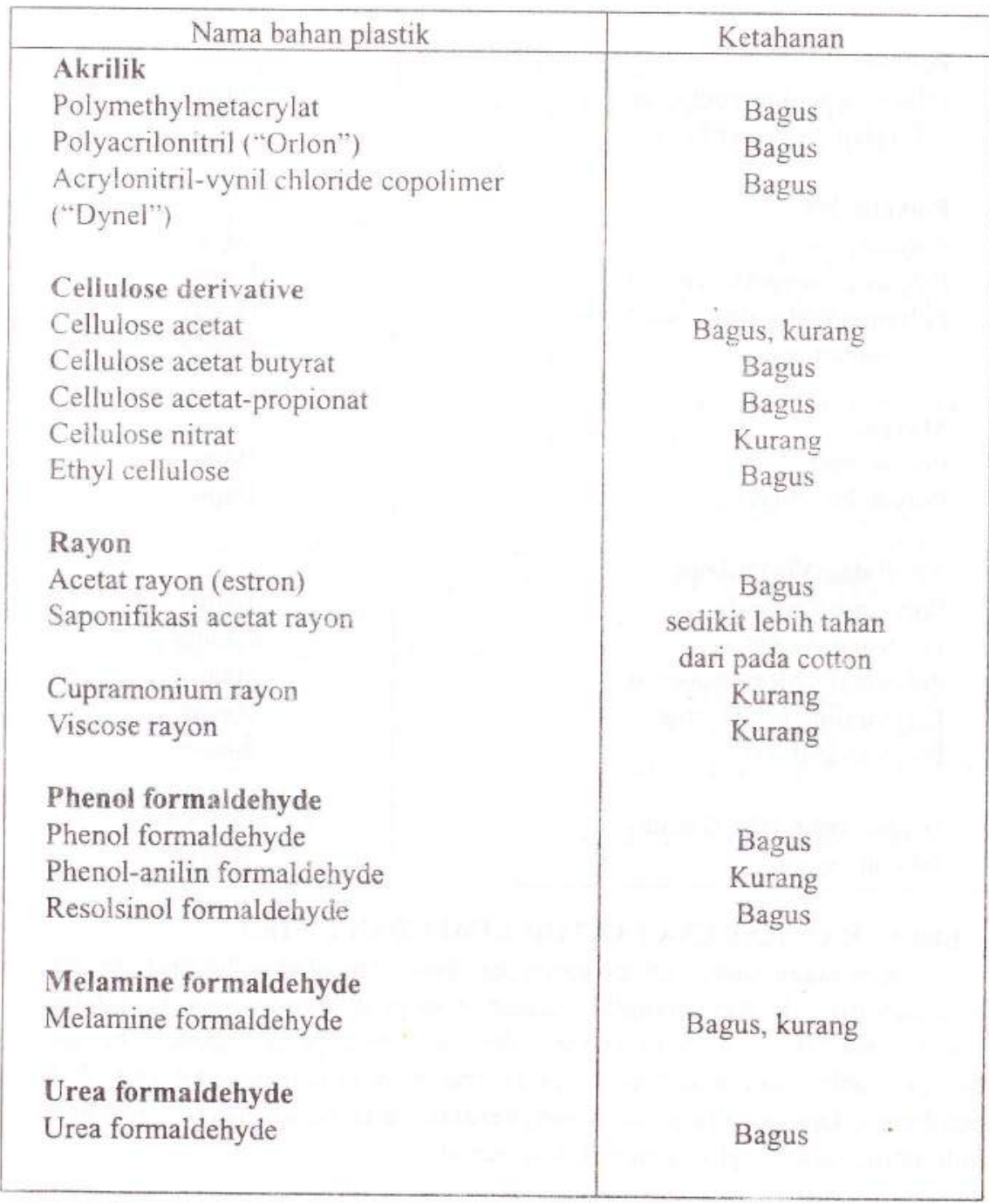

Vol. XII No. 23 Th. $1996 / 1997$ 


\begin{tabular}{|l|c|}
\hline \multicolumn{1}{|c|}{ Nama bahan plastik } & Ketahanan \\
\hline $\begin{array}{l}\text { Protein formaldehyde } \\
\text { Zein formaldehyde ("Vicara") } \\
\text { Casein formaldehyde }\end{array}$ & Bagus \\
Poly Amide & Kurang \\
Nilon & \\
Poliester & Bagus \\
Ethylen glicol terephthalat & \\
("Terylen") ("Fiber IV") & Bagus \\
Polyethylen & \\
Polyethylen & \\
Polytetrafluoroethylen ("Teflon") & \\
Polymonochlorotrifluoroethylen & \\
Polyisobutylen & Bagus \\
Styrene & Bagus \\
Polystyrene & Bagus \\
Polydichlorostyrene & Bagus \\
Vinyl dan Vinylidene & \\
Polyvinyl Chloride & Bagus \\
Polyvinyl Acetat & Bagus \\
Polyvinyl Chloride-Acetat & \\
Polyvinilidene Chloride & \\
Polyvinylbutyral & Bagus \\
Glyptal resin (alkyd resin) & Kurang \\
Silicon resin & Bagus \\
& Bagus \\
\hline
\end{tabular}

Kerusakan karena faktor kimia tergantung pada struktur kimia polimer. Polymer dibagi menjadi 2 group yaitu polimer dengan rantai linier disebut thermoplastik dan polimer dengan banyak sekali rantai cabang yang disebut thermoset. Kekuatan polimer dengan rantai lurus tergantung ukuran molekul dan kekuatan ikatan masingmasing molekul. Jumlah ikatan crosslink pada thermoplastik sangat kecil dibanding dengan thermoset. Polymer jenis thermoset mempunyai rantai cabang yang sangat banyak, oleh karenanya kerusakan yang terjadi pada plastik thermoset biasanya hanya pada permukaan saja.

Polimer thermoplastik dapat mengalami kerusakan karena :

a. Rantai polimer menjadi segmen-segmen polimer yang lebih kecil.

Pada efek ini terjadi pengurangan ukuran molekul, sehingga terjadi penurunan sifat fisika.

b. Beberapa rantai membentuk cross linking.

Terjadinya cross linking pada rantai polimer ini jika hanya sedikit bisa menaikkan sifat fisika, tetapi jika terlalu banyak akan menyebabkan kehilangan elastisitas, terjadinya pengkerutan dan pemecahan (cracking).

c. Beberapa group polimer mengalami perubahan

Efek ini tidak menyebabkan perubahan sifat fisika namun bisa menurunkan sifat elektrik, kelarutan, penyerapan uap air dan lain-lain.

Kompon organik pada umumnya bisa bereaksi secara kimia dengan uap air, ozon dan oksigen. Sehingga bisa menyebabkan kerusakan pada plastik. Polymer yang mengandung gugus hidroksi seperti ester, amida, nitril, acetal dan keton bisa mengalami kerusakan jika terkena air. Polymer yang termasuk tipe ini adalah polyester, polyamide cellulose dan cellulose ester.

Ozon di udara, walaupun adanya hanya sedikit sekali namun mempunyai kekuatan untuk menyerang ikatan rangkap dari atom carbon dengan cara memutus ikatan rangkap. Kompon-kompon yang mengandung gugus tidak jenuh seperti karet alam dan beberapa karet sintetis bisa terserang oleh ozon

Ketahanan plastik terhadap faktor-faktor kimia dan fisika dapat dilihat pada tabel dibawah ini. 


\begin{tabular}{|c|c|c|c|c|}
\hline Nama Bahan & $\begin{array}{r}\text { Kec.Penyalaan } \\
\text { (Buming rate) }\end{array}$ & $\begin{array}{c}\text { Ketahanan } \\
\text { terhadap } \\
\text { asam \& basa }\end{array}$ & $\begin{array}{c}\text { Ketahanan } \\
\text { terhadap } \\
\text { pelant }\end{array}$ & $\begin{array}{c}\text { Ketahanan } \\
\text { terhadap } \\
\text { sinar matahari }\end{array}$ \\
\hline 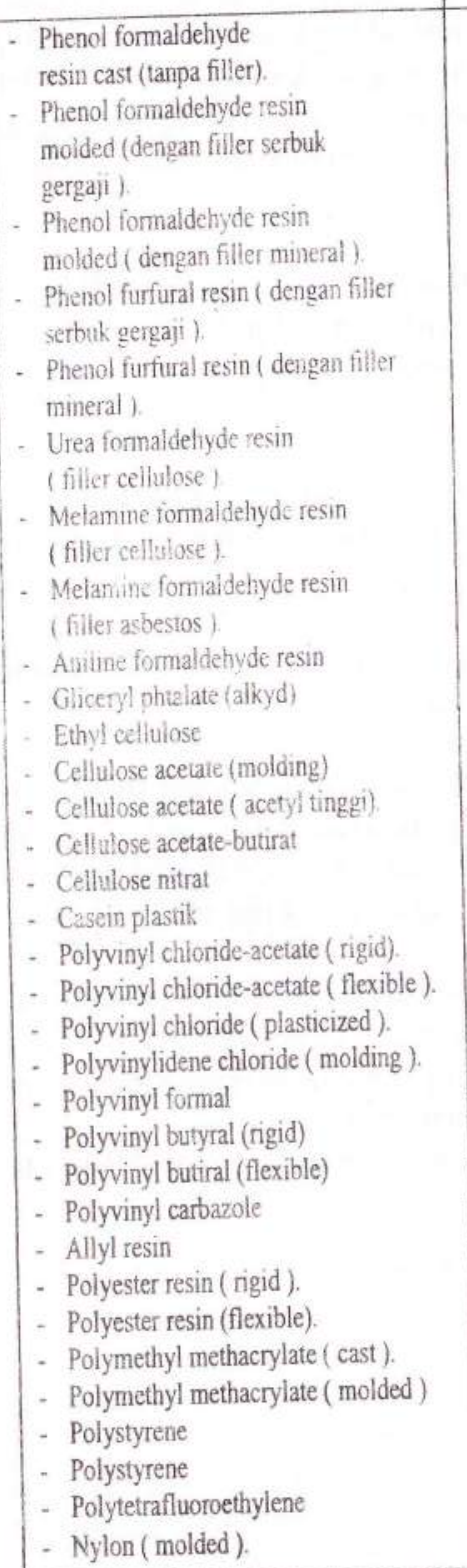 & $\begin{array}{c}\text { tidak ada } \\
\text { sangat lambat } \\
\text { tidak ada } \\
\text { sangat lambat } \\
\text { tidak ada } \\
\text { tidak ada } \\
\text { sangat lambat } \\
\text { sangat lamihat } \\
\text { lambat } \\
\text { lambat } \\
\text { lambat } \\
\text { lambat } \\
\text { sangat cepat } \\
\text { sangat lambat } \\
\text { tidak ada } \\
\text { tidak ada } \\
\text { rendah } \\
\text { tidak ada } \\
\text { rendah } \\
\text { rendah } \\
\text { rendah } \\
- \\
\text { cepat-lambat } \\
\text { cepat-lambat } \\
\text { lambat } \\
\text { lambat } \\
\text { lambat } \\
\text { lambat } \\
\text { tidak ada } \\
\text { tidak ada }\end{array}$ & \begin{tabular}{|c|} 
cukup \\
cukup \\
cukup \\
cukup \\
baik \\
baik \\
cukup \\
baik \\
sangat baik \\
cukup \\
cukup \\
cukup \\
cukip \\
rendal \\
istimewa \\
sangat baik \\
sangat baik \\
istimewa \\
baik \\
baik \\
baik \\
baik \\
sangat baik \\
sangat baik \\
sangat baik \\
sangat baik \\
sangat baik \\
baik \\
istimewa \\
istimewa \\
cukup
\end{tabular} & $\begin{array}{c}\text { istim.ewa } \\
\text { istmewa } \\
\text { istumewa } \\
\text { sangat baik } \\
\text { istimewa } \\
\text { istimewa } \\
\text { sangat baik } \\
\text { baik } \\
\text { larut } \\
\text { lanut } \\
\text { larut } \\
\text { larut } \\
\text { larut } \\
\text { istimewa } \\
\text { cukup } \\
\text { cukup } \\
\text { cukup } \\
\text { istimewa } \\
\text { baik } \\
\text { cukup } \\
\text { cukup } \\
\text { cukup } \\
\text { istimewa } \\
\text { sangat baik } \\
\text { sangat baik } \\
\text { cukup } \\
\text { cukup } \\
\text { cukup } \\
\text { sangat baik } \\
\text { istimewa } \\
\text { istimewa } \\
\end{array}$ & $\begin{array}{l}\text { sangat baik } \\
\text { sangat baik } \\
\text { sangat baik } \\
\text { istimewa } \\
\text { sangat baik } \\
\text { sangat baik } \\
\text { sangat baik } \\
\text { sangat baik } \\
\text { sangat baik } \\
\text { sangat baik } \\
\text { sangat baik } \\
\text { sangat baik } \\
\text { sangat baik } \\
\text { sangat brik } \\
\text { kurang baik } \\
\text { kurang baik } \\
\text { kurang baik } \\
\text { kurang baik } \\
\text { sangat baik } \\
\text { sangat baik } \\
\text { sangat baik } \\
\text { sangat baik } \\
\text { sangat baik } \\
\text { sangat baik } \\
\text { sangat baik } \\
\text { baik } \\
\text { sangat baik } \\
\text { sangat baik } \\
\text { sangat baik } \\
\text { istimewa } \\
\text { sangat baik }\end{array}$ \\
\hline
\end{tabular}

\section{Pencegahan degradasi}

Dari berbagai jenis plastik, PVC merupakan jenis yang mudah terdegradasi oleh panas. Salah satu kelemahan PVC adalah kestabilannya yang rendah pada suhu tinggi. Oleh karena itu untuk memproses PVC diperlukan stabilizer agar tidak terjadi degradasi. Proses degradasi PVC karena panas ditandai dengan adanya perubahan warna. Semakin banyak terjadi perubahan warna maka sifat fisis plastik PVC semakin menurun. Teori perubahan warna ada beberapa macam yaitu :

a. Dehidrochlorinasi atau pengurangan atam $\mathrm{H}$ dan $\mathrm{Cl}$.

b. Anto Oksidasi atau reaksi dengan $\mathrm{O} 2$ yang membentuk hidroperoksida.

Proses degradasi PVC karena panas dapat dicegah dengan penggunaan stabilizer sebagai berikut :

a. Stabilizer timah organik

Stabilizer ini sangat efektif terhadap degradasi panas, mempunyai formula :

$$
\begin{array}{lll}
\mathrm{R} & & \mathrm{Y} \\
& & / \\
& \mathrm{Sn} & \\
\mathrm{R} & & \mathrm{Y}
\end{array}
$$

Senyawa ini mempunyai kemampuan untuk mengikat $\mathrm{HCl}$, membentuk dialkil tin chloride, dengan reaksi kimia sebagai berikut :

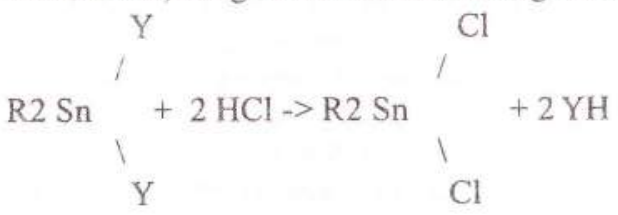

b. Stabilizer logam

Senyawa logam lain yang biasa digunakan sebagai stabilizer terhadap panas adalah timah hitam, $\mathrm{Ba}, \mathrm{Cd}$ dan garam $\mathrm{Zn}$ dari asam organik atau an organik dan senyawa phenol. Bahan ini merupakan akseptor $\mathrm{HCl}$ yang adanya dalam PVC kurang cukup untuk menjaga kestabilan PVC. Stabilizer logam banyak dipergunakan dalam campuran synergis seperti $\mathrm{Ba}$ dan $\mathrm{Cd}$ atau $\mathrm{Ca}$ dan $\mathrm{Zn}$.

c. Stabilizer logam bebas

Stabilizer logam bebas yang penting adalah ester dari asam amino crotonic yang mempunyai formula : 


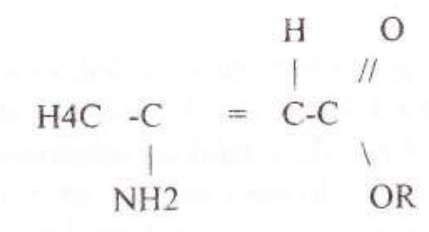

Stabilizer logam bebas yang lain adalah 2 phenylindole, phenyl urea dan di phenyl thio urea.

\section{DAFTAR PUSTAKA}

1. Anonimous, "Manual of PVC Additive ". Ciba Geigy Marienberg GMBH. 1971

2. Anonimous. "Modern Plastic Encyclopedia", Volume 63 No. 10 A, A Mc Graw Hill Publication 1986-1987.

3. Glenn A Greathouse and carl j Wessel : " Deterioration of Material Causes and Preventive Techniques ". Reinhold Publishing Corporation 430 Park Avc. New York, USA.

4. Ronald J Baird. "Industrial Plastics", The Goodheart. Willcox Co, Inc. 